\title{
IMMUNITY IN DIABETES: INFLUENCE OF DIABETES ON THE DEVELOPMENT OF ANTIBACTERIAL PROPERTIES IN THE BLOOD
}

\author{
By RUSSELL RICHARDSON
}

(From the George S. Cox Research Institute, University of Pennsylvania, Philadelphia)

(Received for publication August 8, 1933)

Notwithstanding the well known association of diabetes and infection we have little definite knowledge of the mechanism by which these two conditions affect each other. Since the days of Claude Bernard, clinicians have viewed with alarm either the appearance of infection during the course of diabetes, or, perhaps with less apprehension, the occurrence of diabetes during or following an infection. In considering the coincidence of these disorders one might distinguish between the effect of each upon the other as different though essentially interdependent problems. Various degrees of importance have been accorded to infection in the etiology of diabetes but there is general agreement regarding the harmful effect of infection when occurring during the course of diabetes.

The resistance of the body to infection is attributed in part to the antigen-amboceptor-complement reactions of the blood. We have no knowledge regarding the influence of diabetes on these reactions nor on the formation of amboceptor or complement. The former may be present in the blood, as in natural immunity, or it may be formed following the inoculation of bacteria into the body, as in acquired immunity. Complement appears to be always present and to react with either type of amboceptor. In this study, complement, natural amboceptor and acquired amboceptor, as factors in the antibacterial power of the blood, have been investigated in diabetic and non-diabetic persons to determine whether this part of the protective mechanism of the blood is affected by diabetes.

The complement of the serum was measured in hemolytic and bacteriolytic systems. The bactericidal power of the whole blood was chosen as the best method of determining the native amboceptor $(1,2)$. The formation of agglutinins following inoculation with $B$. typhosus vaccine was taken as the index of formation of acquired amboceptor.

\section{COMPLEMENT}

Method. The hemolytic complement was measured in the sheeprabbit hemolytic system. One-half cc. amounts of a 2 per cent suspension of washed sheep cells with an excess of amboceptor were taken with 
increasing amounts of patients' serum and the total contents of each tube brought up to $3 \mathrm{cc}$. with normal saline. The amount of serum necessary to provide an excess of amboceptor had been determined by preliminary titration. The tubes were then incubated at $37.5^{\circ} \mathrm{C}$. for 1 hour and the titre read as the smallest amount of serum that caused complete hemolysis. The sera were all fresh, the tests being done about 5 hours after the blood had been collected. On account of the variation in sheep cells, both diabetic and normal sera were set up in every series. Whether the patients were taking insulin was noted.

The patients were selected to represent wide variations of diabetes as regards severity, age, use of insulin and state of nutrition. A blood sugar was done on each blood taken.

The bacteriolytic complement was measured by means of the bacteriolytic action of diabetic and non-diabetic sera on $B$. typhosus. An excess of amboceptor in the form of human serum heated to $56^{\circ} \mathrm{C}$. for 30 minutes was added to increasing amounts of patients' sera and $0.1 \mathrm{cc}$. of 24 hour broth culture of the organism. After 24 hours the tubes were cultured on blood agar plates and the titre taken as the lowest amount of serum which completely killed the $B$. typhosus.

Results. In all, 208 diabetic and 102 non-diabetic sera of patients without infection were examined. Of these, 191 diabetic and 97 nondiabetic were measured in the hemolytic system, while 17 diabetic and 5 non-diabetic individuals were used to determine the bacteriolytic complement. The complement titre of the serum in the non-diabetics varied from $0.020 \mathrm{cc}$. to $0.140 \mathrm{cc}$. with an average of $0.056 \mathrm{cc}$., while in the diabetics it varied from $0.030 \mathrm{cc}$. to $0.120 \mathrm{cc}$. with an average of $0.052 \mathrm{cc}$.

In the measurement of bacteriolytic complement similar agreement was found. The titre of both diabetic and non-diabetic sera lay within the same range; namely, between $0.010 \mathrm{cc}$. and $0.075 \mathrm{cc}$.

Furthermore, diabetic patients with infection showed no change in the amount of their complement titre as compared with non-diabetics with infection. Nineteen of the former and 12 non-diabetics were set up. In each group the titre varied between $0.020 \mathrm{cc}$. and $0.080 \mathrm{cc}$. The averages for these groups were $0.040 \mathrm{cc}$. and $0.052 \mathrm{cc}$. respectively.

It is evident from these studies that there is no significant variation from normal in the amount of complement present in the blood of patients with diabetes regardless of whether the blood sugar was high or low and whether or not they were taking insulin. The presence of infection did not appear to alter the complement content of the blood.

\section{BACTERICIDAL EXAMINATIONS}

Since Nuttall in 1888 demonstrated the bactericidal action of whole blood, two methods of measuring the antibacterial titre have been 
commonly selected. Todd (1) and others following Wright used defibrinated blood, while Heist (2) used fresh coagulable blood. Both of these methods were employed in the present study with each patient and control. Five organisms were used throughout the entire series of determinations; namely, B. coli, Pneumococcus, Staphylococcus aureus, Streptococcus hemolyticus and Streptococcus viridans. B. typhosus and $B$. pyocyaneus were also included in some experiments. Because of the length of time necessary to complete the work, cultures which had been growing as laboratory strains for some time were taken so that there would be little variation in their behavior. All of the organisms had been in artificial cultivation for at least a year. Transplants were made at frequent intervals on human blood agar and from these, broth cultures were made 18 hours before the test and incubated at $37.5^{\circ} \mathrm{C}$. Blood sugar determinations were done on all blood specimens.

The defibrinated blood was used according to the method of Todd as given by Ward (3). Defibrination was done in $150 \mathrm{cc}$. flasks containing glass beads and leukocyte counts were made in a number of cases before and after shaking in order to determine the loss in leukocytes. Dilutions of $1 / 10,1 / 100,1 / 1000,1 / 10,000,1 / 100,000$ and $1 / 1,000,000$ of the 18 hour broth cultures were made, and $0.1 \mathrm{cc}$. of each dilution was placed in one of a series of small glass tubes. There was then added to each tube $0.5 \mathrm{cc}$. of defibrinated blood. The tubes were sealed by heat, and placed in a rack attached to an electric motor so as to revolve at the rate of about 6 revolutions per minute. The entire apparatus was placed rotating in the incubator at $37.5^{\circ} \mathrm{C}$. At the end of 24 hours the tubes were opened and cultures were made on human blood agar plates. These were incubated for 48 hours and examined for growth. In each test also, human blood agar plates were seeded with $0.1 \mathrm{cc}$. of the $1 / 100,000$ dilution of each organism and the colonies counted after incubation for 24 hours.

In order to minimize the effect of variations in the number of bacteria present in the 18 hour broth cultures, each determination consisted of one normal and two diabetic persons, except in four instances when only one diabetic was used. As far as possible, attempt was made to get a severe and a mild diabetic to compare with each non-diabetic control. Controls were members of the Institute Staff and medical students.

The fresh coagulable blood was used according to the method of Heist (2). Into sterile, cotton-stoppered test tubes, $85 \times 15 \mathrm{~mm}$., were placed $0.1 \mathrm{cc}$. of the same dilutions of the five organisms as already described, and these overlaid with $0.5 \mathrm{cc}$. of freshly drawn blood. The tubes were gently shaken and allowed to stand until coagulated, when they were placed in the incubator at $37.5^{\circ} \mathrm{C}$. After 24 hours, cultures were made and examined as in the method with defibrinated blood. Sugar determinations were done on all specimens of blood. 
Results. The results of the bactericidal tests by the method using coagulable blood are given in Table I. In these are shown the number of diabetic patients whose blood killed the same number of organisms

TABLE I

Comparison of number of organisms killed by diabetic blood with number killed by non-diabetic blood. (Coagulable blood method)

\begin{tabular}{|c|c|c|c|c|c|c|c|c|c|c|}
\hline \multirow[b]{2}{*}{$\begin{array}{c}\text { Bacteria killed by diabetic blood } \\
\begin{array}{c}\text { Bacteria killed by } \\
\text { non-diabetic blood }\end{array}\end{array}$} & \multicolumn{3}{|c|}{$\begin{array}{c}\text { Diabetics whose } \\
\text { blood killed at least } \\
100 \text { fold less } \\
\text { bacteria than non- } \\
\text { diabetic control }\end{array}$} & \multicolumn{3}{|c|}{$\begin{array}{l}\text { Diabetics whose } \\
\text { blood killed } \\
\text { approximately the } \\
\text { same number of } \\
\text { bacteria as non- } \\
\text { diabetic control }\end{array}$} & \multicolumn{3}{|c|}{$\begin{array}{l}\text { Diabetics whose } \\
\text { blood killed at least } \\
100 \text { fold more } \\
\text { bacteria than non- } \\
\text { diabetic control }\end{array}$} & \multirow[t]{2}{*}{$\begin{array}{c}\text { Total } \\
\text { patients }\end{array}$} \\
\hline & $\frac{1}{10,000}$ & $\frac{1}{1,000}$ & $\frac{1}{100}$ & $\frac{1}{10}$ & 1 & 10 & 100 & 1,000 & 10,000 & \\
\hline $\begin{array}{l}\text { B. coli.................... } \\
\text { Pneumococcus . . . . . . . } \\
\text { Staphylococcus aureus.... } \\
\text { Streptococcus hemolyticus... } \\
\text { Streptococcus viridans...... }\end{array}$ & $\begin{array}{l}3 \\
3\end{array}$ & $\begin{array}{l}3 \\
7 \\
4 \\
6\end{array}$ & $\begin{array}{l}2 \\
8 \\
5 \\
6 \\
3\end{array}$ & $\begin{array}{l}17 \\
12 \\
14 \\
10 \\
16\end{array}$ & $\begin{array}{r}19 \\
14 \\
6 \\
14 \\
14\end{array}$ & $\begin{array}{l}8 \\
4 \\
7 \\
6 \\
2\end{array}$ & $\begin{array}{l}1 \\
3 \\
1 \\
1\end{array}$ & $\begin{array}{l}1 \\
2\end{array}$ & 1 & $\begin{array}{l}46 \\
46 \\
44 \\
44 \\
46\end{array}$ \\
\hline
\end{tabular}

as the normal control and the number whose blood killed less than or more than the control. This method of reporting the results of the tests was adopted because it seemed the simplest way in which the influence of variation in number of bacteria in the broth cultures could be eliminated. The diabetic bloods were compared only with the normal bloods which had been set up at the same time, with the same broth cultures. The difference between the largest and smallest numbers of bacteria in the series of cultures of any one organism was less than the 10-fold dilution which was used between successive tubes of the determinations, so that even if this variation were not considered, the error would be less than one dilution in the series of 6 tubes.

It will be noted that the distribution of cases shows that diabetic patients in general are less able to kill the test bacteria than the nondiabetic controls. This seems to be especially true with the gram positive cocci against which phagocytosis has been shown to be especially effective. It appears that the diabetic tends to be deficient in whatever antibacterial bodies are naturally present in the blood. From Table II it is evident that there is no significant correlation of distribution of the antibacterial power of the blood with variations in the blood sugar. There seems to be some factor in the diabetic, other than the blood sugar at the time of the determination, which influences the bactericidal effect.

A comparison of results of the methods using defibrinated and coagulable blood gave essentially similar results. The same difference between diabetic and non-diabetic bloods could be recognized in both. The method with coagulable blood generally showed a slightly higher bactericidal titre than did the method with defibrinated blood. 
TABLE II

Comparison of organisms killed by diabetic blood containing over $200 \mathrm{mgm}$. and under $200 \mathrm{mgm}$. of sugar to those killed by non-diabetic blood

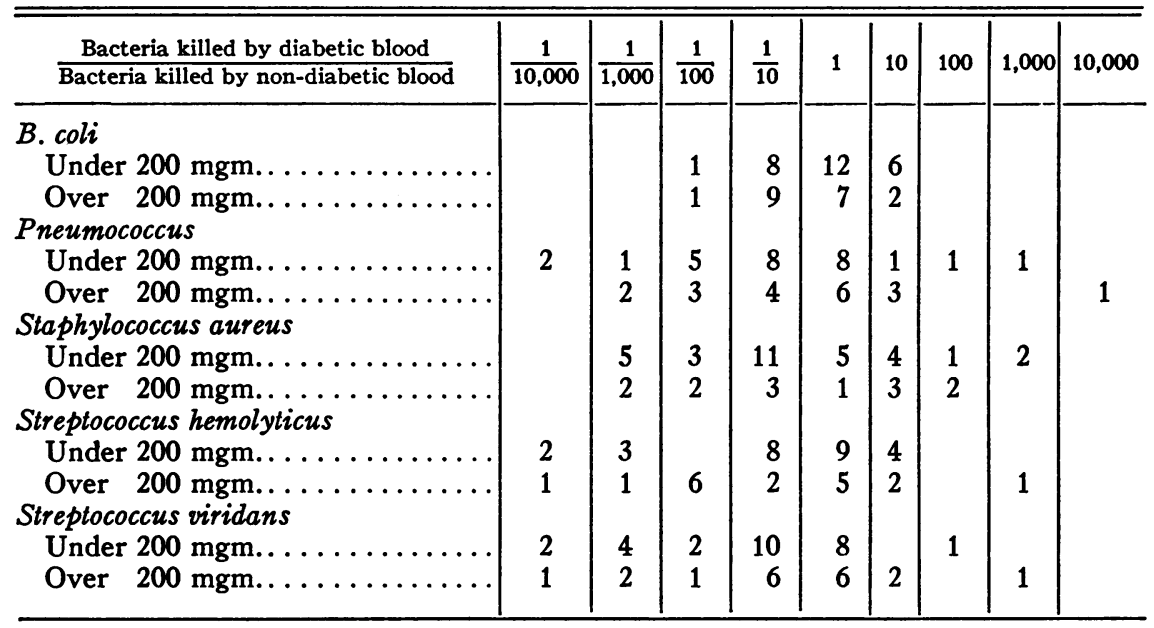

Conclusions. Diabetic whole blood, regardless of the level of its blood sugar, has in general a weaker bactericidal property than has non-diabetic whole blood as tested by standard methods.

\section{ANTIBODY FORMATION}

In addition to the presence of complement and natural amboceptor, immunity against bacterial infection is influenced by the ability of the body to form antibodies for specific infections. In order to compare the formation of an acquired antibody in diabetic and non-diabetic persons, the response to typhoid vaccine was investigated.

Methods. Three doses, 500 million, 1000 million and 1000 million respectively of $B$. typhosus vaccine ${ }^{1}$ were given subcutaneously at intervals of seven days to 41 diabetic and 39 non-diabetic persons. Record was kept of the occurrence of local or general reactions in both series, reactions, if present, being noted as slight, moderate or severe.

The vaccine used was freshly made in order to get the highest possible agglutinative titre in the blood. It was given first to the diabetic patients and later to the non-diabetic controls. There was probably very little difference in the potency of the vaccine in the two series as the last inoculation was given within 8 weeks of the time of making the vaccine.

Blood for determination of agglutinative titre was taken 2 weeks and 10 weeks after the last dose. The titre was determined by Dreyer's (4) macroscopic method, using typhoid antigen killed and preserved by

${ }^{1}$ Furnished through the courtesy of Lederle Laboratories Inc. for this work. 
formalin. The same strain of $B$. typhosus from which the vaccine was made was procured from the makers for the purpose of making the antigen. The same antigen was used throughout the 8 weeks. Known positive and negative sera were run with each determination, the positive serum regularly clumping the antigen at a dilution of $1 / 20,480$.

The non-diabetic controls consisted of the entering class of nurses at the Methodist Episcopal Hospital in Philadelphia. The diabetic patients were ambulatory cases from the clinic, and varied in severity, though none were in such condition that giving the vaccine would be a dangerous procedure. It was impractical to get the patients of the same young age group as the controls though most of the former were under 40 years. Frequent blood and urine examinations were made, and on the basis of these, as well as of the clinical condition, the patients were divided into three groups; namely, those in good, fair and poor clinical condition. The first were those who had always a normal blood sugar with no sugar in the urine and who felt generally well. The second group comprised those who were in fair condition and who more or less successfully maintained their diets; their blood sugar levels lay between 140 and $200 \mathrm{mgm}$. per $100 \mathrm{cc}$., and glycosuria was sometimes present. The third were those who always had a blood sugar over $200 \mathrm{mgm}$. and sugar in most, if not all, of the urine specimens.

TABLE III

Agglutinative titre of diabetic patients and non-diabetic controls

\begin{tabular}{|c|c|c|c|c|c|c|c|c|c|c|}
\hline & $1 / 20 \mid 1 / 40$ & $1 / 80$ & $1 / 160$ & $1 / 320$ & $1 / 640$ & $\mid 1 / 1280$ & $1 / 2560$ & $|1 / 5120|$ & $|1 / 10240|$ & $1 / 20480$ \\
\hline \multicolumn{11}{|c|}{2 weeks after vaccine } \\
\hline $\begin{array}{c}\text { Non-diabetics.............. } \\
\text { Diabetics............. } \\
\text { Good clinical condition } \\
\text { Fair clinical condition } . \\
\text { Poor clinical condition }\end{array}$ & & 1 & $\begin{array}{l}1 \\
2\end{array}$ & $\begin{array}{l}2 \\
1 \\
1\end{array}$ & $\begin{array}{l}6 \\
2 \\
4\end{array}$ & $\begin{array}{l}1 \\
7 \\
3 \\
2 \\
2\end{array}$ & $\begin{array}{l}4 \\
5 \\
1 \\
3 \\
1\end{array}$ & $\begin{array}{r}6 \\
10 \\
1 \\
6 \\
3\end{array}$ & $\begin{array}{l}7 \\
6 \\
2 \\
4\end{array}$ & $\begin{array}{r}20 \\
2 \\
1 \\
1\end{array}$ \\
\hline
\end{tabular}

10 weeks after vaccine

\begin{tabular}{|c|c|c|c|c|c|c|c|c|c|c|}
\hline $\begin{array}{l}\text { Non-diabetics.............. } \\
\text { Diabetics............... } \\
\text { Good clinical condition } \\
\text { Fair clinical condition.. } \\
\text { Poor clinical condition }\end{array}$ & $\begin{array}{l}1 \\
1\end{array}$ & $\begin{array}{l}4 \\
1 \\
3\end{array}$ & $\begin{array}{l}2 \\
1 \\
1\end{array}$ & $\begin{array}{l}1 \\
6 \\
1 \\
2 \\
3\end{array}$ & $\begin{array}{l}2 \\
6 \\
1 \\
2 \\
3\end{array}$ & $\begin{array}{r}15 \\
4 \\
9 \\
2\end{array}$ & $\begin{array}{l}4 \\
4 \\
1 \\
2 \\
1\end{array}$ & $\begin{array}{r}11 \\
3 \\
2 \\
2 \\
1\end{array}$ & 19 & 1 \\
\hline
\end{tabular}

Results. In Table III are shown the results of the agglutination tests. It is quite evident that there is a marked difference in the titre of the diabetic and non-diabetic series at the end of both 2 weeks and 10 weeks. Fifty per cent of the non-diabetics agglutinated at a dilution 
of $1 / 20,480$ compared with 5 per cent of the diabetics, and 84 per cent of the non-diabetics agglutinated at $1 / 5120$ or above, compared with 44 per cent of the diabetics. The persistence of titre of the serum for 8 weeks is much less in the diabetics than in the non-diabetics. At the end of this time 81 per cent of the non-diabetics were found to agglutinate at a dilution of $1 / 5120$ or more compared with 7 per cent of the diabetics. The effect of the high blood sugar on the formation of antibodies does not appear to be definite, though there is perhaps a slightly less effective formation in the patients whose diabetic condition is described as poor.

The author wishes to acknowledge with thanks many helpful criticisms and suggestions by Dr. Herbert Fox and Dr. J. Harold Austin. Thanks are due also to Miss Elizabeth F. Barth, Miss Peggy C. Kostal and Miss Jessie Paul for technical assistance.

\section{SUMMARY}

Complement in the blood of diabetic patients does not differ in amount from that in the blood of non-diabetics. This is true whether or not infection is present.

The antibacterial power of the blood of diabetic patients as measured by standard methods tends to be less than that of non-diabetics.

Diabetic patients are less able than non-diabetic controls to form agglutinins following their inoculation with typhoid vaccine.

From these studies it appears that any deficiency in the antibacterial reactions of the blood of the diabetic comes rather from impairment of the amboceptor than from any lack of amount or activity of the complement. This is true of both the natural amboceptor as shown by the bactericidal test, and of the acquired amboceptor, as shown by formation of agglutinins.

\section{BIBLIOGRAPHY}

1. Todd, E. W., Brit. J. Exper. Path., 1927, viii, 1. A Method for Measuring the Increase or Decrease of the Population of Hemolytic Streptococci in the Blood.

2. Heist, G. D., Solis-Cohen, S., and Solis-Cohen, M., J. Immunol., 1918, iii, 261. The Bactericidal Action of Whole Blood with a New Technic for its Determination.

3. Ward, H. K., J. Exper. Med., 1930, li, 675 and 685 . Observations on the Phagocytosis of the Pneumococcus by Human Whole Blood. I and II.

4. Dreyer, G., Gibson, A. G., and Walker, E. W. A., Lancet, 1916, i, 766. Further Remarks on Agglutination Tests in Inoculated Persons, and the Influence of Febrile Conditions on Inoculation Agglutinins. 